o. Benignus Józef Wanat OCD

\title{
Prace rewaloryzacyjne w klasztorze \\ i nowe wyposażenie wnętrza kościoła św. Józefa karmelitów bosych w Poznaniu w latach 1984-1990
}

\section{Historia zabytku sztuki}

Karmelici bosi przybyli do Poznania w 1618 roku. Po uzyskaniu zezwolenia władz miejskich i biskupa poznańskiego Andrzeja Opalińskiego (17 V 1618) założyli klasztor na Wzgórzu św. Wojciecha ${ }^{1}$. W ogrodzie nabytym od Elżbiety Michanówny zbudowali - początkowo drewniany - klasztor pod wezwaniem św. Józefa, poświęcony przez biskupa pomocniczego Gaspara Hapa dnia 2 lipca $1618 \mathrm{roku}^{2}$. W latach 1635-1687, na gruncie zapisanego im dworu przez Barbarę Orzelską, wybudowali murowany barokowy klasztor i kościół św. Józefa³. Architektami i budowniczymi kościoła św. Józefa byli: Jerzy Catenaci oraz Krzysztof Bonadura starszy i Krzysztof Bonadura młodszy ${ }^{4}$. W głównym ołtarzu kościoła znajdował się łaskami słynący obraz św. Józefa, patrona świątyni. Po ukończeniu prac budowlanych i wyposażeniu wnętrza kościół został konsekrowany dnia 13 lipca 1687 roku przez bpa Hieronima Wierzbowskiego ${ }^{5}$. W oddanym do użytku klasztorze mieściło się studium teologii dla kleryków. Na mocy decyzji króla pruskiego Fryderyka Wilhelma, wydanej dnia 5 lipca 1801 roku, klasztor uległ

${ }^{1}$ Archiwum Prowincji Krakowskiej Karmelitów Bosych [dalej: APKB] w Czernej, sygn. AKP 1, Historia conventualis, s. 4-5.

2 Tamże, s. 5; B. J. Wanat OCD, Zakon Karmelitów Bosych w Polsce. Klasztory karmelitów i karmelitanek bosych 1605-1975, Kraków 1979, s. 204.

3 Tamże, s. 61; Archiwum Główne Akt Dawnych w Warszawie, Metryka Koronna 186, Regestrum secundum privilegiorum et inscriptionum Cancellariae Maioris S. R. M. annorum 1639-1641 , k. 138-139.

${ }^{4}$ S. Loza, Architekci i budowniczowie w Polsce, Warszawa 1954, s. 33, 44.

${ }^{5}$ Historia conventualis, dz. cyt., s. 172 c. 
kasacie 6 . Zabudowania klasztorne oddano do celów wojskowych. Mieściły się w nim administracja i biura wojska pruskiego. Kościół początkowo służył za magazyn, a od 1831 roku jako ewangelicki kościół garnizonowy. Wnętrze jego zostało przebudowane. Usunięto barokowe ołtarze. W prezbiterium postawiono klasycystyczny ołtarz z obrazem św. Józefa, namalowanym przez berlińskiego malarza Augusta Teodora Karelowskiego ${ }^{7}$.

Po odzyskaniu niepodległości Polski budynki klasztorne zajęło wojsko polskie, a kościół św. Józefa od 24 lipca 1919 roku stał się garnizonowym kościołem wojska polskiego. W tym okresie wnętrze świątyni otrzymało nowe wyposażenie, które uległo zniszczeniu w czasie okupacji hitlerowskiej.

Karmelici bosi odzyskali swoją własność w 1945 roku w stanie ruiny. Odbudowa i rewaloryzacja zabytku sztuki trwała wiele lat. Obecne wyposażenie kościoła wykonane zostało w latach 1985-1990.

Powodem zmiany wystroju wnętrza w latach osiemdziesiątych ubiegłego stulecia była konieczność zwrotu głównego ołtarza ojcom bernardynom do kościoła w Woźnikach, skąd był przywieziony 30 lat temu. Dnia 7 lutego 1983 roku franciszkanie przybyli wraz z pracownikami w celu dokonania rozbiórki i przewiezienia ołtarza św. Józefa do swego odzyskanego kościoła w Woźnikach. Prace demontażowe trwały $5 \mathrm{dni}$. Jako wynagrodzenie za konserwację, złocenia i nowe tabernakulum pancerne franciszkanie złożyli wynagrodzenie w wysokości 350 tysięcy $\mathrm{zt}^{8}$.

Prostą ścianę prezbiterium kościoła św. Józefa, przy której do tej pory znajdował się ołtarz z Woźnik, przykryto na okres przejściowy żaglowym płótnem, na którym powieszono obraz Matki Bożej Częstochowskiej na tle narodowej flagi i maryjnych emblematów. Pośrodku prezbiterium zaś ustawiono drewniany ołtarz soborowy do odprawiania nabożeństw. Najświętszy Sakrament umieszczono okresowo w kaplicy Matki Bożej Ostrobramskiej ${ }^{9}$. Kapituła klasztorna zmuszona została do podjęcia decyzji o budowie nowego ołtarza do prezbiterium. Przeor klasztoru o. Anastazy od św. Eliasza Gęgotek podejmował konsultacje $\mathrm{z}$ architektami i plastykami w celu opracowania projektu nowego ołtarza. Przedstawione zostały kapitule przynajmniej dwa projekty. Z powodu kończącej się trzyletniej kadencji dotychczasowego przełożonego kapituła klasztoru posta-

${ }^{6}$ B. J. Wanat OCD, Zakon Karmelitów Bosych w Polsce..., dz. cyt., s. 240.

7 M. Orłowicz, Ilustrowany przewodnik po poznańskiem, Warszawa 1920, s. 42.

${ }^{8}$ Archiwum Karmelitów Bosych w Poznaniu, Liber memorabilium Conventus OCD Posnaniae, t. 2 ab Anno Domini 1964, s. 589-590.

9 Tamże, s. 589. 
nowiła zaczekać z realizacją budowy ołtarza do czasu wyboru nowego przełożonego. Kapituła prowincjalna, obradująca od 5 do 12 czerwca 1984 roku w Krakowie, mając na uwadze prace renowacyjne i budowlane w klasztorze w Poznaniu, wybrała przeorem tego klasztoru o. Mariusza od Matki Bożej Wniebowziętej (Józefa Jaszczyszyna), doktora socjologii, który przez dwie kadencje (1978-1984) na stanowisku przeora w Krakowie zdobył potrzebne doświadczenie, dokonując renowacji kościoła i konwentu oraz wznowienia kultu św. Józefa - patrona miasta Krakowa ${ }^{10}$.

Po objęciu urzędu przeora w Poznaniu o. Mariusz zapoznał się ze stanem faktycznym klasztoru oraz planami budowlano-remontowymi. Doszedł do przekonania, że prace będą trwały długo. Dlatego postanowił najpierw zdobyć potrzebne fundusze, przygotować plany budowy, uzyskać zgodę konserwatora zabytków na rewaloryzację kościoła i zakupić potrzebne materiały budowlane. $\mathrm{W}$ międzyczasie podjął porządkowanie klasztoru i jego otoczenia we własnym zakresie. Wykonanie planu rewaloryzacji wnętrza kościoła $\mathrm{z}$ budową nowego ołtarza do prezbiterium, dostosowanego do architektury barokowej, świątyni zlecił architektowi inż. Józefowi Dutkiewiczowi z Krakowa. Przygotowane przez architekta plany nowego ołtarza św. Józefa zatwierdziła do realizacji Rada Prowincjalna w Krakowie dnia 26 stycznia $1987 \mathrm{roku}^{11}$.

\section{Remonty i prace budowlane w klasztorze}

Najpierw wykonano nową bramę przed furtą, bramę do ogrodu i główne drzwi dębowe do kościoła. Przy furcie urządzono gabinet lekarski dla stomatologa. Pomalowano klatkę schodową do zakonnego chóru i korytarze ${ }^{12}$. Wyremontowano klatkę schodową i korytarz prowadzący z salki misyjnej do refektarza. Wystawę misyjną w przedłużeniu prezbiterium przekazano do muzeum misyjnego w Czernej, a na tym miejscu urządzono salkę najpierw dla III Zakonu Karmelitańskiego, a następnie przeznaczono na zakrystię ${ }^{13}$. Dla brata Wawrzyńca

\footnotetext{
${ }^{10}$ Archiwum Karmelitów Bosych w Krakowie, Acta capituli conventus cracoviensis ab anno 1936 ad annum 1997, t. 2, zob. akt pod datą 16.09.1979 r. (brak paginacji).

${ }^{11}$ APKB w Czernej, sygn. AKP 42, Delineamenta altaris magni pro ecclesia S. P. N. Joseph Carmelitarum Discalceatorum Posnaniae.

${ }_{12}^{12}$ Liber memorabilium, s. 612.

13 Tamże, s. 615.
} 
Mikołaja Radkiewicza urządzono nową stolarnię, a jego dotychczasową, znajdującą się w kompleksie zabudowań gospodarczych (w podwórzu), przeznaczono dla najętych stolarzy pracujących dla klasztoru.

Bracia studenci filozofii podjęli akcję uporządkowania ogrodu od strony południowej klasztoru. Założyli nowe kwietniki, wykonali nowe alejki. W części parkowej założono ławy do siedzenia. Potem wykonali alejkę od furty klasztornej do ul. Działowej z nowymi płytkami z betonu ${ }^{14}$. Wielką pomocą był o. Józef Kołodziejczyk - ekonom konwentu, który podejmował starania o materiały budowlane i zajmował się ich transportem ${ }^{15}$.

Do poważniejszych prac należy przeprowadzenie (od października 1984 roku) kapitalnego remontu refektarza, usytuowanego na parterze północnego skrzydła klasztoru. Na czas remontu urządzono refektarz w sali misyjnej za prezbiterium (obecna zakrystia). Po zdjęciu płyt pilśniowych i podłogi okazało się, że na głębokości $1 \mathrm{~m}$ znajduje się warstwa gruzu na piwnicznym sklepieniu. Podjęto decyzję o usunięciu gruzu i pogłębieniu refektarza. W trakcie usuwania gruzu napotkano na stare urządzenia betonowe $\mathrm{z}$ okresu użytkowania budynku przez wojsko. Po oczyszczeniu sklepienia piwnicznego położono legary żelazne i betonową wylewkę, a na nich posadzkę z jasnej „morawicy” ${ }^{16}$. Poprowadzono nowe instalacje elektryczne i nagłośnieniowe oraz po wymalowaniu wnętrza powieszono na sklepieniu trzy świeczniki mosiężne wieloramienne, wykonane w Krakowie. Stolarze wykonali nowe okna i drzwi wejściowe na korytarz i przejściowe do kuchni z futrynami, przerobili dotychczasowe stoły i ławy oraz zainstalowali zaplecki drewniane z podwójnych pasów. Na ścianach powieszono kilka obrazów z XVIII wieku. Refektarz odzyskał swoje piękno, proporcje i dostojeństwo. W piwnicy pod refektarzem urządzono nastrojową sklepioną salę. Usunięto z niej gruz i położono ceramiczną, brunatną posadzkę $e^{17}$.

W przedłużeniu prezbiterium za głównym ołtarzem urządzono okazałą zakrystię z nowymi szafami na liturgiczne paramenty, szaty i argenterię oraz mszały i kultowe podręczniki. Natomiast starą zakrystię zamieniono na kaplicę Pana Jezusa Ukrzyżowanego. Zabytkowy korpus Chrystusa z XVIII wieku odnowił rzeźbiarz Janusz Bajka. Usytuowany został w nastawie ołtarzowej z podświetlonym i wyeksponowanym relikwiarzem Krzyża Świętego. Aranżacja wnętrza kaplicy stwarza odpowiedni klimat do kontemplacji.

\footnotetext{
14 Tamże, s. 627.

15 Tamże, s. 662.

16 Tamże, s. 635-643.

17 Tamże, s. 705.
} 
Staraniem o. Mariusza przeprowadzono renowację i konserwację 34 zabytkowych obrazów z XVII i XVIII wieku na krużgankach klasztornych, sprowadzonych przed laty przez o. Leonarda Kowalówkę OCD z klasztoru ss. karmelitanek bosych na Wesołej w Krakowie. Pochodzą one ze skasowanych w XVIII wieku klasztorów karmelitów bosych w Krakowie: pod wezw. Niepokalanego Poczęcia NMP (obecnie szpital św. Łazarza) i Świętych Michała Archanioła i Józefa (obecnie Muzeum Archeologiczne). Renowacji i konserwacji dokonała dyplomowa konserwator mgr Cecylia Wójtowicz w Krakowie ${ }^{18}$.

\section{Renowacja i nowe wyposażenie kościoła}

Po ukończeniu pracy w klasztorze podjęto akcję odgruzowania sklepień kościoła. Okazało się, że z powodu wielkiego ciężaru gruzu sklepienia pękały. Dla przeprowadzenia tej akcji od strony ogrodu wybudowano rusztowanie $\mathrm{z}$ „rękawem” na gruz z poddasza kościoła. W ramach tej akcji usunięto ok. 40 ton gruzu $^{19}$. Po usunięciu gruzu pęknięcia na sklepieniach zalano mleczkiem cementowym oraz całe sklepienie ocieplono szklaną watą. W tym samym czasie trwały prace remontowe pokrycia dachowego kościoła. Wymieniono zbutwiałe belki konstrukcji wiązań dachowych, na gzymsach koronnych założono blachę miedzianą oraz nowe rynny i rury spustowe $\mathrm{z}$ miedzi. Prace blacharskie wykonał Pinczak z synem (z Poznania). Przełożono również na całym kościele ceramiczną dachówkę. Założono nowe okna w kościele. Przywrócono zamurowane dotąd okno w prezbiterium nad głównym ołtarzem, umieszczając w nim witraż z symbolem Ducha Świętego, wykonany z Zakładzie Żeleńskich w Krakowie ${ }^{20}$. Również przywrócono zamurowane półokrągłe okna w ramionach transeptu na wysokości okien w bocznych kaplicach. Barokowe, boczne ołtarze $\mathrm{z}$ ramion transeptu, pochodzące $\mathrm{z}$ kościoła $\mathrm{w}$ Buku, prawie po 30 latach oddano $\mathrm{z}$ powrotem pierwotnemu właścicielowi, jako nieharmonizujące stylistycznie z nowym wystrojem świątyni św. Józefa ${ }^{21}$. Prace tynkarskie na zewnątrz kościoła wykonali Kazimierz Józefiak z Puszczykowa i Teodor Spitalniak

${ }^{18}$ Wykaz i opis zabytkowych obrazów zob. w: B. J. Wanat OCD, Zakon Karmelitów Bosych w Polsce, s. 248-251.

19 Tamże, s. 630.

${ }^{20}$ Tamże, s. 658 .

${ }^{21}$ Tamże, s. 653. 
z Poznania. We wnętrzu świątyni założono nowe instalacje elektryczne i do radiofonii. Wykonawcą był Leszek Gaweł z Krakowa. Samą radiofonię wykonał mgr inż. Felicjan Tomaszewski z Kościana. Na elewacjach głównej nawy pomiędzy zdwojonymi pilastrami odkryto i przywrócono zamurowane, półokrągło zwieńczone konchowe nisze $\mathrm{w}$ dwóch poziomach. Oczyszczono z kilku warstw farby wszystkie sztukaterie. Ze względu na liczne braki spowodowane zniszczeniem wojennym, wykonano nowe sztukaterie według starych wzorów ${ }^{22}$. Prace te wykonali sztukatorzy poznańscy: Marian i Walenty Domanieccy, Jan Kąkolewski, Ryszard Maćkowiak, Ryszard Handke, Alojzy Jakubowski i Przemysław Maciejowski ${ }^{23}$. Usunięto gipsowe ozdoby z główkami aniołów nad bocznymi kinkietami i zastąpiono je tarczowymi, złoconymi kinkietami odblaskowymi $\mathrm{z}$ ornamentem kwiatowym, rzeźbionymi w drzewie przez Waldemara Nowakowskiego w Krakowie ${ }^{24}$. Mosiężne wiszące świeczniki wieloramienne wykonał Janusz Nakoneczny w Krakowie ${ }^{25}$. Portal z czarnego marmuru dębnickiego pod chórem muzycznym prowadzący z kruchty do nawy świątyni wykonał Stanisław Cekiera z Dębnika. Natomiast soborowy ołtarz pośrodku prezbiterium i boczne ambonki z czarnego marmuru dębnickiego wykonał Zakład Kamieniarski Mieczysława Cekiery z Woli Filipowskiej k. Krzeszowic ${ }^{26}$. Nowe schody wejściowe do kościoła od ul. Działowej wykonała z piaskowca „Sobolów” firma Kazimierza Steca z miejscowości Kobyle w 1986 roku. Boczne poręcze przy schodach oraz kratę na chór kościelny wykonał Błotny. Gruntowny remont organów kościelnych przeprowadził Zbigniew Kozub, a prospekt organowy odnowił Stanisław Przybylski (?). Po wykonaniu wszystkich prac instalacyjnych, tynkarskich i sztukatorskich wnętrze świątyni zostało wymalowane przez Eugeniusza Gajewskiego wraz z synami Jerzym i Mirosławem, po zatwierdzeniu kolorystyki przez konserwatora zabytków ${ }^{27}$. Równocześnie trwały prace instalacyjne centralnego ogrzewania z potrzebnymi urządzenia i komorą ogrzewczą pod prezbiterium kościoła. Pod posadzką umieszczono kanały z kratkami, doprowadzające ciepło do wnętrza świątyni. Wykonawcą była firma Krzysztofa Gruchota z Poznania. Ze względu na zniszczoną posadzkę postanowiono po-

22 Tamże, s. 655.

${ }^{23}$ Wiadomość z ustnej relacji kierownika budowy o. dra Mariusza Jaszczyszyna.

${ }^{24}$ Liber memorabilium, s. 658.

25 Tamże.

${ }^{26}$ Dane uzyskane od o. dra Mariusza Jaszczyszyna, przeora i kierownika opisywanej budowy w Poznaniu.

27 Tamże. 
łożyć marmur w całej świątyni. Podłoże betonowe pod posadzkę przygotowali bracia klerycy i br. Miłosław Osowicki pod kierunkiem o. Jerzego Gogoli, zawodowego murarza, który pracował w tym zawodzie przed wstąpieniem do zakonu. Położono w prezbiterium posadzkę marmurową z kostki z brunatnego „tardoszu” o wymiarach $40 \mathrm{x} 40 \mathrm{~cm}$, a w nawie i bocznych kaplicach jasną ",morawicę". Posadzkę wykonał kamieniarz z Krakowa Edward Jamrozik.

\section{Główny ołtarz}

Zaprojektowany przez architekta Józefa Dutkiewicza główny ołtarz w swej konstrukcji nawiązuje do barokowego wnętrza świątyni. Wykonali go z miękkiego drzewa sosnowego na miejscu zatrudnieni stolarze Ryszard Sobkowiak i Czesław Tarnecki. Jest architektoniczny, retabulum flankują dwie pary zdwojonych pilastrów z każdej strony z korynckimi złoconymi kapitelami, na podwójnych cokołach, dźwigającymi regularne belkowanie, z przerwanymi, uszatymi przyczółkami i rzeźbą Chrystusa na krzyżu pośrodku zwieńczenia w złocistych promieniach. W profilowanych płycinach pilastrów znajdują się pasy płyt marmuru brunatnego, „tardoszu”, nadając szlachetny walor nastawie ołtarzowej. Płytki z tegoż marmuru zdobią również fryz i dolne boczne cokoły oraz predellę. Korpus Chrystusa Ukrzyżowanego w zwieńczeniu ołtarza, kapitele pilastrów w nastawie i na tabernakulum oraz drzwiczki wyrzeźbił Michał Batkiewicz $\mathrm{z}$ Krakowa. Metalowe ramy okienne, pancerne i złocone tabernakulum na mensie ołtarzowej wykonane zostały w warsztacie ślusarsko-mechanicznym inż. Stanisława Słowika w Krakowie. Pośrodku retabulum umieszczono prostokątny obraz świętego Józefa z Dzieciątkiem Jezus, zwieńczony łukiem pięciolistnym wklęsło-wypukłym. Obraz jest kopią oryginału pędzla flamandzkiego malarza br. Łukasza od św. Karola (Charles Sibrecque) OCD, namalowanego w Rzymie w 1668 roku dla nieistniejącego dziś kościoła Świętych Michała Archanioła i Józefa Karmelitów Bosych w Krakowie ${ }^{28}$. Św. Józef, którego obraz słynie łaskami, ogłoszony został decyzją magistratu patronem Miasta Krakowa w 1715 roku. Oryginał znajduje się obecnie w kościele Niepokalanego Poczęcia NMP Karmelitów Bosych w Krakowie przy ul. Rakowickiej 18. Kopię tego obrazu do ołtarza głównego w Poznaniu wykonał artysta malarz Jerzy Kumala z Krakowa na zamówienie o. Mariusza Jaszczyszyna. Ramę do obrazu wykonał stolarz Julian Ple-

${ }^{28}$ Por. B. J. Wanat OCD, Kult św. Józefa Oblubieńca NMP u Karmelitów Bosych w Krakowie, Kraków 1981, s. 88. 
wa z Krakowa. Polichromię całego ołtarza oraz złocenia wykonał artysta Jerzy Łudzik z Krakowa.

W miejsce bocznych ołtarzy w ramionach transeptu umieszczono w złoconych ramach duże kompozycje malarskie, Boże Narodzenie i Upadek Chrystusa pod ciężarem krzyża, namalowane techniką olejną przez A. Tschautscha w 1878 r. Przed remontem kościoła znajdowały się w prezbiterium tejże świątyni. Również w nowych złoconych ramach umieszczono w transepcie kościoła nad wejściem do kaplic św. Krzyża i Matki Bożej Ostrobramskiej obrazy św. Teresy od Jezusa i św. Jana od Krzyża, Doktorów Kościoła, namalowane przez Stefana Bukowskiego dla klasztoru SS. Karmelitanek Bosych w Poznaniu.

W tym też czasie przeprowadzono gruntowną konserwację barokowej ambony i wyzłocenia rzeźb Ewangelistów i Matki Bożej wykonaną przez krakowskich złotników ${ }^{29}$. Odnowiono w kruchcie kościoła nagrobek Alberta (Wojciecha) Konarzewskiego, szczególnego dobrodzieja klasztoru z XVII wieku. W przedłużeniu kruchty w miejscu dawnego składu kościelnego urządzono nastrojową kaplicę z obrazem Miłosierdzia Bożego, namalowanym przez Danutę Waberską z Poznania. Mosiężne, wiszące latarnie do kruchty wykonał Józef Uruszczak z Krakowa. Po przeprowadzeniu prac budowlanych, konserwatorskich i malarskich wnętrze świątyni otrzymało nowy wystój meblarski według projektu architekta J. Dutkiewicza: 42 ławy z drzewa dębowego neobarokowe, stalle dębowe do prezbiterium oraz 4 konfesjonały w tymże stylu, również dębowe, wykonane na miejscu przez wyżej wymienionych stolarzy ${ }^{30}$.

\section{Samotnia św. Rafała Kalinowskiego}

Dla duszpasterstwa specjalistycznego o. przeor Mariusz Jaszczyszyn postanowił wykorzystać dawną kryptę grobową pod kościołem, służącą jako magazyn i składowisko różnych przedmiotów. Po ich usunięciu na inne miejsce przystąpiono do wywożenia gruzu i odkopania kilka warstw przysypanych piaskiem zbutwiałych trumien z resztkami kości pogrzebanych tam w XVII i XVIII wieku zmarłych zakonników i dobrodziejów klasztoru. Doczesne szczątki wywieziono ze czcią na pobliski zabytkowy cmentarz i pogrzebano w jednej mogile karmelitańskiej, oznaczając ją krzyżem i tabliczką informacyjną. Instalacje elektryczne i oświetlenie wykonał Józef Szymański z Poznania, a posadzkę z płytek klinkie-

\footnotetext{
${ }^{29}$ Liber memorabilium, s. 661.

30 Tamże, s. 663.
} 
rowych położył Tadeusz Olszewski. Po oczyszczeniu elewacji, uzupełnieniu tynków, wymalowaniu i położeniu posadzki założono nowe okna i drzwi wejściowe z ogrodu - tak urządzono „Samotnię Świętego Rafała Kalinowskiego”31. Samotnia wyposażona została w ołtarz z obrazem św. Rafała Kalinowskiego, nowe krzesła do siedzenia oraz urządzenia nagłaśniające. Odbywają się tam rocznicowe akademie, misteria Męki Pańskiej, naukowe konferencje i sympozja, dni skupienia, zebrania duszpasterskie dla różnych grup stowarzyszeń i organizacji kościelnych etc.

Na kwiatowym klombie przed fasadą kościoła na cokole postawiono w 1989 roku kamienną rzeźbę św. Rafała Kalinowskiego, wykonaną przez br. Kazimierza Szczecinę OCD ${ }^{32}$.

Po ukończeniu wszystkich prac renowacyjnych przeprowadzonych w okresie sześciu lat (dwie kadencje) pod kierunkiem o. Mariusza Jaszczyszyna, przeprowadzone zostały w odnowionej świątyni wielkopostne rekolekcje dla wiernych, przeprowadzone przez zaproszonego ks. bpa Stanisława Nowaka z Częstochowy. Na zakończenie rekolekcji w dniu 19 marca 1990 roku, patronalnej uroczystości kościoła św. Józefa, ks. bp Nowak poświęcił nowy ołtarz i wyposażenie odnowionej świątyni. Na tę uroczystość przybyli liczni goście, dobrodzieje klasztoru, rzemieślnicy i artyści zatrudnieni przy renowacji świątyni, główny architekt inż. Józef Dutkiewicz z Krakowa oraz wojewódzki i miejski konserwator zabytków sztuki w Poznaniu.

Za nowe wyposażenie wnętrza kościoła i rewaloryzację całego klasztoru o. Mariusz Jaszczyszyn otrzymał w roku 1991 od Marka Rostworowskiego, ministra kultury i sztuki w rządzie Jana Krzysztofa Bieleckiego, wyrazy uznania i sześcioramienny świecznik mosiężny, nagrodę od pani Magdaleny Brzezińskiej, miejskiego konserwatora zabytków i odznaczenie od Henryka Nowakowskiego, wojewódzkiego konserwatora zabytków sztuki w Poznaniu.

\footnotetext{
31 Tamże, s. 175-185.

${ }^{32}$ Liber memorabilium, s. 726.
} 


\section{Riassunto}

\section{I lavori di restauro nel convento e il nuovo arredamento}

della Chiesa di San Giuseppe dei Carmalitani Scalzi a Poznań negli anni 1984-1990

Il convento e la chiesa dei carmelitani scalzi a Poznań costruita nel 1618 è primo e il più antico tempio in Polonia dedicato a San Giuseppe. La chiesa è barocca, progettata dagli architetti Giorgio Catenacci e Cristoforo Bonadura. Nell'altare principale si trovava un tempo l'immagine di San Giuseppe. Nel convento ci fu la facoltà di teologia per i seminaristi. Il 5 luglio 1801 per ordine del re prussiano Federico Guglielmo il convento venne trasformato in una caserma. A partire dal 1831 venne trasformato in un tempio evangelico di guarnigione; ciò provocò il cambiamento dell'arredamento. A partire dal 1919, qundo Polonia riacquistò la sua indipendenza dopo le spartizioni, fu trasformato in una chiesa cattolica per i militari. Subito dopo la seconda guerra mondiale nel 1945, l'edificio, in stato deplorevole, venne restituito ai carmelitani. La ricostruzione durò molti anni. Lodierno arredamento del tempio fu fatto negli anni 1983-1990. Il 19 marzo 2010 l'arcivescovo di Poznań, Stanisław Gądecki proclamò la chiesa il Santuario di San Giuseppe per la diocesi di Poznań. 